\title{
Yoga: Freedom from History
}

\author{
Rajiv Malhotra* \\ American-Indian author, USA
}

Submission: June 23, 2017; Published: July 19, 2017

*Corresponding author: Rajiv Malhotra, American-Indian author, USA, Email: rajivmalhotra2007@gmail.com

\section{Opinion}

When I first moved to the United States 4 decades ago, I was struck by the efforts made by individuals, civic societies and the American government to in still in Americans a strong historical identity. Secular American society is filled with historical societies, with practically every American town engaged in the recording, analysis and preservation of past events, whether significant or not. National monuments of patriotic historical events dominate state capitals. Similarly, genealogy is a thriving discipline in the West with both amateurs and professionals engaged in the collection and recording of family and community histories. And New York City's parades by various ethnicities show the importance given to incorporate every minority's sense of history into the overall historical American tapestry.

In comparison, I'd come of age in India with relative indifference to the knowledge of the past exploits of the Punjabi jati, my community by birth. There was none of the preciseness that characterizes the collection of dates, names, record of past events, genetic analysis and family stories and occupies so many individuals and institutions in the West. Instead, my questions about the past were usually answered by a broad, big picture rendition of family lore, an emphasis on a few impactful events and a casual disregard for dates, timelines and other such literal details that are usually important in historical compilations. Part fact, part embellishment, what counted of the retelling was the lesson from the past that needed to be conveyed.

Not surprisingly, as I began my study of cultures, I realized that this secular preoccupation in the West too has its roots in Judeo-Christian traditions. The distinct attitudes toward history described above of Westerners and Indians have been shaped by the markedly different approaches of knowing the divine between the Judeo-Christian and Dharmic faiths. As I explain in my latest book Being Different: An Indian Challenge to Western Universalism (Harper Colins 2011), in the Judeo-Christian traditions, the reliance on one or more historical events is crucial to the knowledge of God, to spiritual life and to salvation. Revelation comes from a transcendent God who personally intervenes at a specific place, point and set of circumstances to "save" mankind and offer the truth. The bedrock of such religions is therefore this historical event and leads to an almost obsessive compilation and study of historical details of such interventions, making them what I call "history-centric". The Dharmic faiths in contrast, do not depend on literal historical events in the same manner. They posit that truth can be found not only externally, but also within, by each person, in every given age or time. With everyone endowed with the potential of achieving in this very life, the state of sat-chit-ananda or blissful knowledge of and unity with God, there have emerged numerous techniques such as yoga, meditation etc., shorn of any historical grand narratives, timelines or institutional authority, to discover the truth. This approach, quite different from history-centrism, is one that I call the path of embodied knowing. While there is much merit to the investigation, recording and analysis of past events, in the realm of religion, there are serious problems with the attempt by institutional authorities to precisely pin down and historicize sacred stories. For one, many of the critical claims asserted as fact and central to salvation- the virgin birth, crucifixion and resurrection in Christianity for example- simply cannot be verified. (Nor do they constitute scientific claims because they are not falsifiable either). Additionally there are several contradictory claims of these events producing conflicts both within religions and among rival ones, leading to disastrous events on the ground. A clash of civilizations could be viewed as really a clash of the official and non-negotiable historical accounts of competing faiths.

Attempts to transform a particular culture's sacred myths into hiorical fact and then universalize this also appears to be blatantly ethnocentric. In the case of Judaism and Christianity, God played favorites, "choosing" them (of course)-Israel and the Church respectively-to become the recipient of His largesse. While anointed thus by the divine, the sacred literature of all other cultures is dismissed, quite self-servingly, as pre-historic mythology. Myth, a word that is evocative of the imaginary, the fictional and the fantastical (but not fact), then becomes the weapon with which rival spiritual traditions are delegitimized. The Judeo-Christian roots of the view that history and myth 
are mutually exclusive are evident in one of the letters to early Christian congregations in the New Testament which asserts: "We did not follow cleverly devised myths when we made known to you the power and coming of our Lord Jesus Christ, but we had been eyewitnesses of His majesty" (2 Peter 1:16).

Dharma traditions, however, deal with their past through neither history alone nor myth alone, but through "itihasa". Truth and not mere history is the concern of itihasa. Itihasa, combines history and myth. Truth is not dependent or contingent upon history; rather, history is a manifestation of it. The dharmic relation between history and myth is thus not at all comparable to the Western relation between truth and fiction. Most Hindus tend to view the past events in their traditions in a fluid manner. Time after all recurs in endless cycles. Historical narratives play a role especially to the beginner on the spiritual journey, but to the dharma practitioner, it is the virtues illustrated in the narratives and not the literal facts that are paramount. Sri Aurobindo emphasizes the point that while convinced of the historicity of Lord Krishna, His historical significance is superseded by the values or the behaviors (attitudes) that His life conveys.

Because the study of itihasa is intended to bring about a change within and to ultimately transcend space and time itself through Yoga, Indians by and large do not feel the pressure to present their myths as absolute history and exhibit a casualness to the details of the lives of even their most cherished avatars and saints. Indians then are unprepared and ill-equipped to deal with the powerful apparatus and elaborate processes at work in the transformation of Western myths into hard and literal facts. The attempt to then universalize this history and impose a monoculture on the entire world is the "Western Universalism" that I decry in Being Different. In the book, I further explore the difference in the attitudes toward the past between the Dharmic and Judeo-Christian traditions.

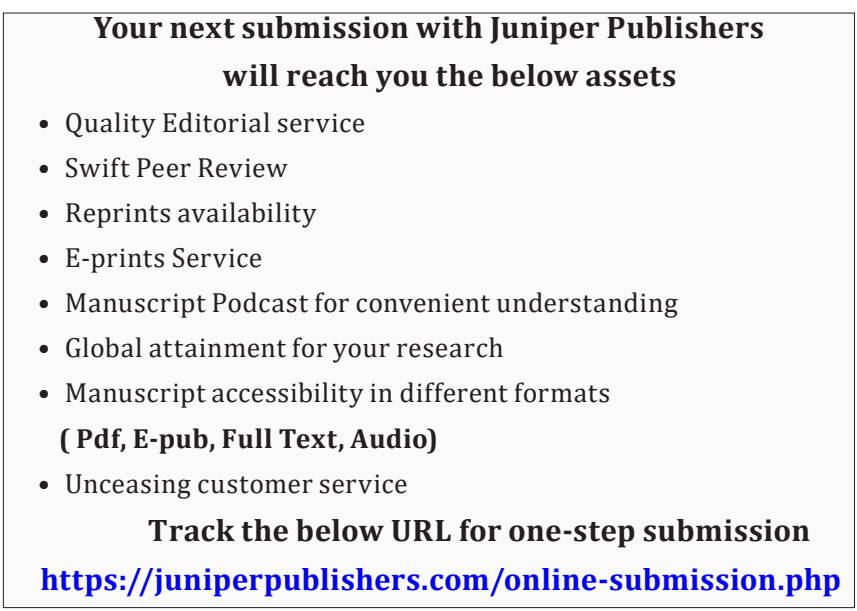

